Biljana Čubrović

UDK 811.111'243(73):81'342.41

University of Belgrade

DOI: 10.4312/linguistica.57.1.59-72

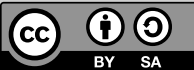

\title{
THE ACOUSTIC CHARACTERISTICS OF NON-NATIVE AMERICAN ENGLISH VOWELS
}

\section{INTRODUCTION}

It is a commonplace to say that non-native speakers (NNSs) differ in how they pronounce their L2 sounds from native speakers (NSs). Some studies have shown that speakers of different language backgrounds have difficulty acquiring the vowel contrasts of English whose vowel inventory is rather dense. Spanish learners of English find it challenging to discern the difference between English /i:/ and /I/ (Flege et al. 1997; Escudero/Boersma 2004) probably because they both sound like the Spanish /i/. A similar acoustic and perceptual pattern is reported for Mandarin (Thomson et al. 2009), and Norwegian (Iverson/Evans 2007).

The two groups of speakers whose vowels are analyzed in this study belong to different native language backgrounds with noticeable differences in the vowel inventories. Serbian ${ }^{1}$ is traditionally described as a language that has five vowels, $/ \mathrm{i}$ e a o u/, which counts as one of the statistically preferred vowel inventories in the languages of the world. The consonants are much more diversified (twenty-five in number). The prosodic system of Serbian tends to be somewhat complex and is based on the notion of pitch accents that are according to the Vukovian tradition four in number: short falling (SF), short rising (SR), long falling (LF) and long rising (LR), e.g. pita (Eng. pie), voda (Eng. water), moda (Eng. fashion), and mada (Eng. though), respectively. According to the traditional linguistic approach, set up by Vuk Stefanović Karadžić in the nineteenth century, pitch accents and vowel length are merged and represent a single phonemic category. In short, this approach presupposes that vowel quantity is a prosodic phenomenon, which makes Serbian an isolated case. To the best of my knowledge, the category of phonemic length in the languages of the world is not interpreted as part of the prosodic system. In line with this, some notable attempts have been made to re-interpret the prosodic system of Serbo-Croatian and bring it closer to the current linguistic understanding, which presupposes that tone and vowel quantity are not merged into a single category. Jakobson 1937 [1962] proposes a novel approach where quantity and

* biljana.cubrovic@fil.bg.ac.rs

1 The language that was once referred to as an official language of Yugoslavia was SerboCroatian. I will use the newer term, Serbian, in this study, which is an official language of Serbia. However, when analysing the viewpoints of other linguists, I will retain the term that they originally used. The coinage Bosnian-Croatian-Serbian (often abbreviated to BCS) is another widespread term used outside of the region of former Yugoslavia, but it has not gained ground in Bosnia, Croatia or Serbia. 
pitch of the Serbian vowels are factored out as two distinct dimensions, which was later adopted in several studies on the suprasegmental properties of this language (Browne/ McCawley 1965; Inkelas/Zec 1988).

Considering other L2 studies that investigate various phonetic properties of English and Serbian, Sokolovic-Perovic (2009) recognizes 10 vowels in the Serbian vowel system, adopting the Jakobsonian approach in her study. On the other hand, Krebs-Lazendic and Best (2013) oppose to this view accepting the Vukovian traditional approach of the description of the Serbian vowel system.

I will adopt the Jakobsonian approach that presupposes the existence of ten different vocalic segments which can be combined with tones (high or non-high). Another phonetic issue arises when short and long vowels are subgrouped into two separate phonemic categories. The debate relates to the possible difference in the vowel quality of long and short vowels, but I will not discuss this in detail in this paper. Serbian is described as one of the quantity languages, and its vowel inventory contains ten vowels (five long and five short): /a e i o u/ and /a: e: i: o: u:/. The dialect of Serbian investigated here is the Belgrade dialect and it utilizes all ten vowel segments. On the other hand, some dialects of Serbian (e.g. the speakers in the region of the city of Pirot in south-eastern Serbia) do not always use the long-short phonemic distinction.

The American English vowel inventory is much more complex than Serbian. This study focuses on nine of its monophthongs, as produced by NSs of English and NNSs of English with a substantial length of residence ${ }^{2}$ in the States. A full set of American English monophthongs contains eleven different segments (Yavas 2011: 77-78), /i i e $\varepsilon$ $\mathfrak{x}_{\Lambda} \mathrm{u} \cup 0 \supset \mathrm{d} /$, in the words beat, bit, bait, bet, bat, but, boot, put, boat, bought, and pot respectively. These vowels are usually treated as simple vowels, even though some may be diphthongized, /e/ and /o/ in particular and /i/ and / $\mathrm{u} /$ also, but to a smaller degree. Yavaş (ibid.) points out that the vowels of bite, bout and void are the main diphthongs in AE.

Furthermore, AE makes use of the phonological distinction tense/lax in the description of vowels. One of its component parts is the difference in the phonetic duration between tense and lax vowel segments. This much debated phonological distinction has been widely used in AE, and it is one of the pairs of binary features (tense/lax) that distinguishes the vowel of beat from the vowel of bit. Lax vowels are usually shorter, but the vowel of bat is phonetically long even though it is lax.

This study will explore the acoustic features of nine AE monophthongs out of eleven. The vowels of bait and boat are eliminated from the experiments due to several reasons. Firstly, they are somewhat diphthongal in AE. Also, the participants in this study who are originally Serbian were almost exclusively taught the British variety of English at school and would probably diphthongize these vowels even more.

The phonetic vowel quality is acoustically analyzed with the help of vowel formants. The first three formants are usually employed to point out even the most subtle phonetic differences. However, many phonetic studies use only the first two formants to specify the vowel quality of every vowel segment, and these are referred to as $F_{1}$ and

2 The term length of residence is usually abbreviated to LOR. The acronym is used henceforth in this paper. 
F2. When $F_{1}$ and $F_{2}$ are presented on a graph, they resemble a vowel diagram which is based on the articulatory features of vowels. This semblance enables easier identification of vowels in acoustic studies and this principle will be adopted in this study. The first formant is inversely related to tongue height. The higher the vowel, the lower the first formant. The second formant is related to the degree of backness. The more front the vowel, the higher the second formant.

Earlier research on the acoustic characteristics of American English vowels provides measurements of vowel formants, which can be compared to the $F_{1}$ and $F_{2}$ obtained in this study. The most widely cited experiment on the acoustics and perception of English vowels was carried out by Peterson and Barney (1952). They recorded 2 repetitions of 10 vowels in the phonetic environment $/ \mathrm{hVd} /$, as spoken by 33 male speakers, 28 female speakers and 15 children. They measured the first three vowel formants $\left(\mathrm{F}_{1}-\mathrm{F}_{3}\right)$, formant amplitudes and fundamental frequency for every token. The measurements were made subjectively, at a time slice that they judged to be "steady state," which is one of the most important limitations of this study. Coarticulation could not be taken into account, as it usually occurs at segment boundaries. Peterson and Barney's experiment triggered further phonetic research on the acoustics of vowels, theories of vowel recognition and perception. Hillenbrand et al. (1995) conducted a very similar study with more speakers of American English, who were also screened for dialect ( $87 \%$ came from the state of Michigan). Their experiment included 12 vowels of AE in the same phonetic context as the Peterson and Barney study dealt with, but vowels in Hillenbrand et al's experiment were also recorded in isolation. Acoustic measurements were taken from a steady state portion of each vowel in order to replicate Peterson and Barney's experiment. Table 1 shows the measurements of $F_{1}$ and $F_{2}$ of those vowels which are the focus of the present study. Only the acoustic values for male speakers are taken from Hillenbrand et al. (1995: 3103) and given below, also in compliance with the present study.

Table 1: Mean values of $F_{1}$ and $F_{2}$ of vowels produced by 45 men (adapted and taken from Hillenbrand et al. (1995)

\begin{tabular}{|l|l|l|l|l|l|l|l|l|l|}
\cline { 2 - 10 } \multicolumn{1}{c|}{} & $/ \mathrm{i} /$ & $/ \mathrm{I} /$ & $/ \varepsilon /$ & $/ \mathfrak{m} /$ & $/ \mathrm{\Lambda} /$ & $/ \mathrm{u} /$ & $/ \mathrm{U} /$ & $/ \mathrm{J} /$ & $/ \mathrm{a} /$ \\
\hline $\mathrm{F}_{1}$ & 342 & 427 & 580 & 588 & 623 & 378 & 469 & 652 & 768 \\
\hline $\mathrm{F}_{2}$ & 2322 & 2034 & 1799 & 1952 & 1200 & 997 & 1122 & 997 & 1333 \\
\hline
\end{tabular}

\section{EXPERIMENT}

\subsection{Participants}

Ten NSs of Serbian who live in the United States and four NSs of American English took part in the experiment. All fourteen participants are male.

At the beginning of the recording session, each participant was asked to fill out a questionnaire. The Serbian participants were asked to report the LOR in the United States and language(s) spoken at home. The Serbian participants were also asked to rate their own English fluency on a scale from 1 to 5 ( 5 being the highest) at the time 
of relocation from Serbia and at the time of recording. They were all born in Belgrade, Serbia (except for one participant who was born in the south of Serbia, but lived in Belgrade for 27 years prior to moving to the US) and lived there until they moved to the States. They all live in Atlanta, GA. Their age ranges from 35-44. Nine of them had lived in Atlanta for more than 12 years at the time of the recording. Seven out of ten speakers mostly speak Serbian at home, the other three speak Serbian at home as well (but interchangeably with other languages). The fact that all ten Serbian speakers use their mother tongue at home is important for this study because the phonetic interference from this language may influence the pronunciation of English vowels. Nine Serbian participants speak exclusively English at work. Speaker IS speaks English and Serbian at work. Therefore, all participants use both English and Serbian on a daily basis.

NSs were asked to report on their place of residence and languages spoken. All 4 live in the North-East of the United States. Two were undergraduate students at Cornell University, Ithaca, NY, and two were employees (former and present) of the same University. The assumption is that age differences will not affect the production of vowels. Table 2 summarizes this information.

Table 2: Background information on participants

\begin{tabular}{|l|l|l|l|l|l|l|}
\hline Subject & Sex & Age & $\begin{array}{l}\text { L2 fluency } \\
\text { (self-evaluat- } \\
\text { ed) then/now }\end{array}$ & Place of residence & $\begin{array}{l}\text { Length of } \\
\text { residence }\end{array}$ & $\begin{array}{l}\text { Language(s) } \\
\text { spoken at home }\end{array}$ \\
\hline Serbian NSs (NNs) & \multicolumn{7}{|l|}{} \\
\hline GV & M & 40 & $4 / 5$ & Atlanta, GA & 12 & Mostly Serbian \\
\hline SG & M & 41 & $3 / 5$ & Atlanta, GA & 23 & Serbian/English \\
\hline MR & M & 40 & $2 / 5$ & Atlanta, GA & 14 & Mostly Serbian \\
\hline MS & M & 40 & $1 / 4$ & Atlanta, GA & 15 & Mostly English \\
\hline IS & M & 44 & $2 / 4$ & Atlanta, GA & 15 & Mostly Serbian \\
\hline NC & M & 37 & $2 / 4$ & Atlanta, GA & 16 & Mostly Serbian \\
\hline VG & M & 42 & $2 / 3$ & Atlanta, GA & 8 & Mostly Serbian \\
\hline NN & M & 36 & $2 / 4$ & Atlanta, GA & 13 & Mostly Serbian \\
\hline MP & M & 35 & N/A & Atlanta, GA & 14 & English/Spanish \\
\hline UZ & M & 45 & $3 / 4$ & Atlanta, GA & 16 & Mostly Serbian \\
\hline English NSs & \multicolumn{5}{|l}{} \\
\hline MB & M & 19 & & New York City, NY & & English \\
\hline TC & M & 70 & & Ithaca, NY & & $\begin{array}{l}\text { English, } \\
\text { some French }\end{array}$ \\
\hline PI & M & 19 & & & & English \\
\hline MI & M & 73 & & Pittsburgh, PA & & English \\
\hline
\end{tabular}




\subsection{Materials and Recording Procedures}

The acoustic experiments target nine vowels of AE in the following monosyllabic words: beat, bit, bet, bat, but, boot, put, bought and pot. The words were all embedded in the frame sentence "Say again," and repeated three times in a random order, giving a total of 270 (10 speakers x 3 repetitions x 9 vowels) tokens for Serbian NSs and 108 (4 speakers $x 3$ repetitions x 9 vowels) tokens for English NSs, totalling 378 repetitions.

All Serbian English recordings were made using Sennheiser noise-cancelling headphones and a Sony laptop computer in Praat, Version 5.3.51 (Boersma/Weenink 2013). The NSs of American English were recorded in a sound-attenuated booth in the Phonetics Laboratory at Cornell University. Participants were given the set of sentences in a Power Point presentation, and only one sentence was presented on a slide at a time. They were also given the opportunity to familiarize themselves with the sentences before the recording started. After they had got acquainted with the materials, the participants were instructed to read the sentences "as naturally as possible."

\subsection{Analysis and Discussion}

The recordings were digitized at $22,000 \mathrm{~Hz}$ and analyzed using the Praat software for acoustic analysis of speech (Boersma/Weenink 2013). All elicited materials were first manually labelled and vowel segmental acoustic features measured with the help of a script designed by DiCanio (2013). This script generated 8 acoustic measures: vowel duration, $\mathrm{F}_{1}, \mathrm{~F}_{2}, \mathrm{~F}_{3}$, center of gravity, standard deviation, skewness, and kurtosis. Only $F_{1}$ and $F_{2}$ are analysed in the present study. For both $F_{1}$ and $F_{2}$, the mean value from each of three equal intervals over the duration of the vowel was extracted. All values that were unexpectedly high or low were checked manually by the author and corrected wherever necessary. The mean values of $F_{1}$ and $F_{2}$ for every token are shown in all the graphs that follow.

The vowels are presented in groups in the analysis that follows. The acoustic measurements of the first two formants for NSs are given first. They are followed by those of NNSs. $F_{1}$ is plotted on the vertical axis, and $F_{2}$ on the horizontal one in graphs. Each marker in graphs represents one repetition. Wherever necessary, comments are provided for individual speakers' idiosyncratic speech or possible phonetic interference from their mother tongue.

\subsubsection{High Vowels /i i /}

The first pair of vowels are those of beat and bit. These two vowels are treated as long and short respectively in British English. In AE, they are most often described as tense and lax. NSs clearly differentiate between the two, which is shown in Graph 1. On the other hand, NNSs have a tendency to merge the two vowels. Another observation is related to the span of $\mathrm{F}_{2}$ values for NSs. It is wider for $/ \mathrm{i} /$ when compared to NNSs, and it ranges from $2032 \mathrm{~Hz}$ to $2892 \mathrm{~Hz}$. $\mathrm{F}_{1}$ values are relatively close in the two groups of participants (see Tables 3 and 4). 


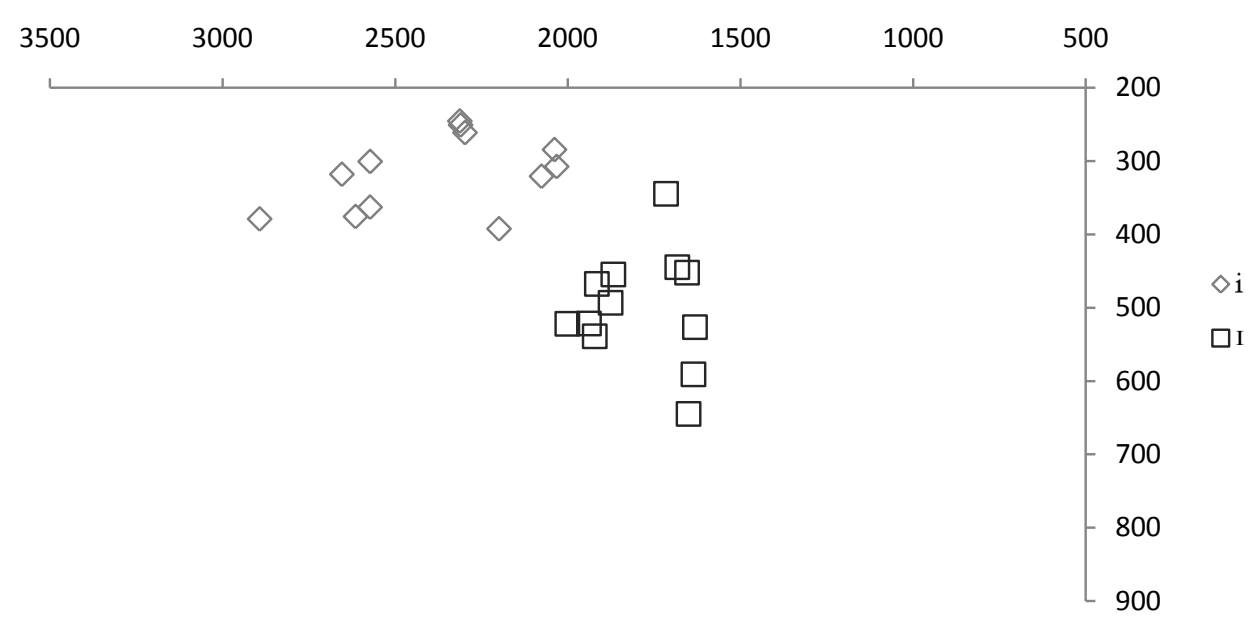

Graph 1: $F_{1}$ and $F_{2}$ of $/ i_{1} /$ for NSs

NNSs' vowel merger of high vowels /i/ and /I/ may be accounted for by the fact that Serbian language background speakers rely heavily on the phonetic duration when distinguishing between these two vowels. They transpose this phonetic property from L1 (Serbian) into L2. The merger is not observed in speaker SG, who has the longest LOR in the States (23 years). Similarly, the acoustic characteristics of $/ \mathrm{I} / \mathrm{of}$ speaker MS, whose LOR is 15 years, approximate the NSs production of this vowel.

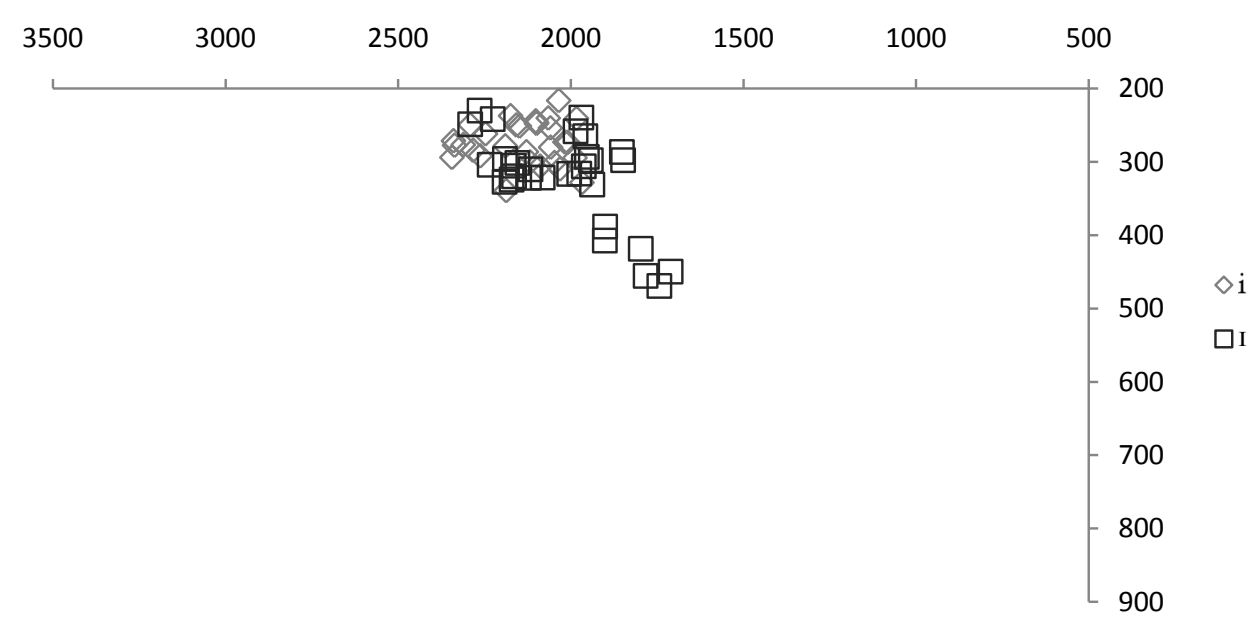

Graph 2: $\mathrm{F}_{1}$ and $\mathrm{F}_{2}$ of $/ \mathrm{i} \mathrm{I} /$ for NNSs

\subsubsection{High Vowels / u $\mathbf{~ / ~}$}

The next pair of vowels are the vowels of boot and put. Similar to / I I/, these two vowels are treated as long and short in British English. In AE, /u/ is tense and $/ \mathrm{v} /$ is lax. NSs 
clearly differentiate between the two, which is shown in Graph 3, i.e. there is no overlapping of $/ \mathrm{u} /$ and $/ \mathrm{v} /$.

On the other hand, NNSs have a tendency to merge the two vowels, where they should produce an $/ \mathrm{u} / \mathrm{vowel}-\mathrm{like}$ quality. The non-native speaker participants consistently produce $F_{1}$ of $/ \mathrm{u} /$ with a lower frequency. This makes this vowel quality a higher vowel and closer to $/ \mathrm{u} /$ in the speech of the NS group. NNSs obviously disregard the quality difference between the two English vowels and rely more on the phonetic duration, similar to the $/ \mathrm{i} /-/ \mathrm{I} /$ pair.

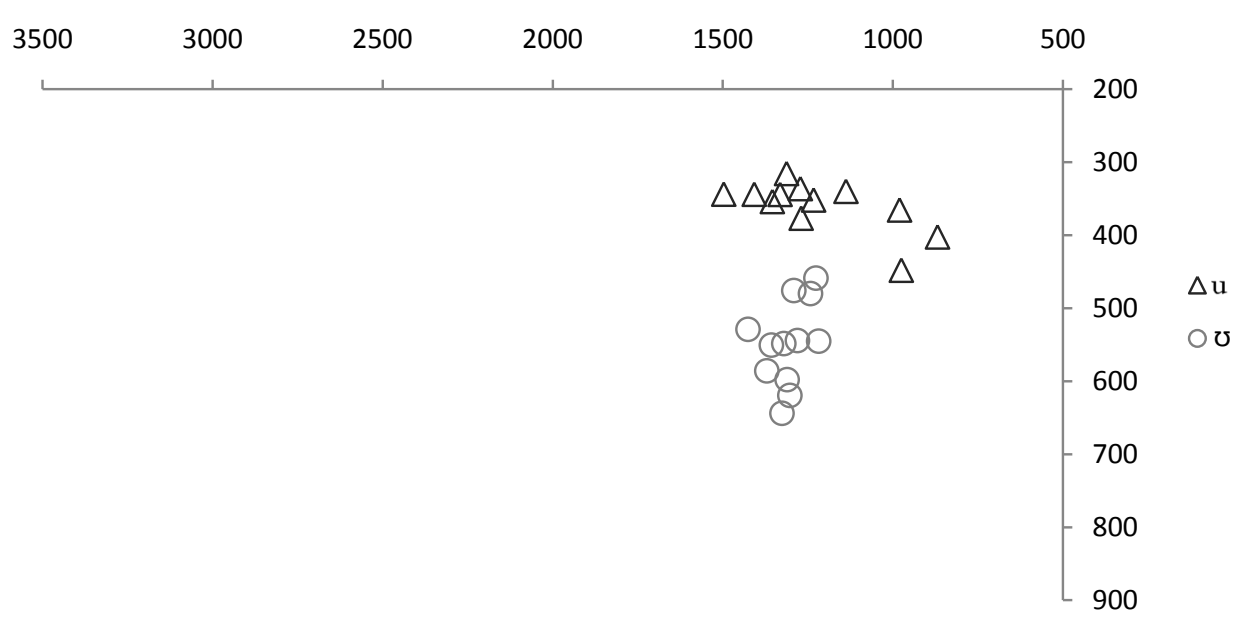

Graph 3: $F_{1}$ and $F_{2}$ of $/ u$ v/ for NSs

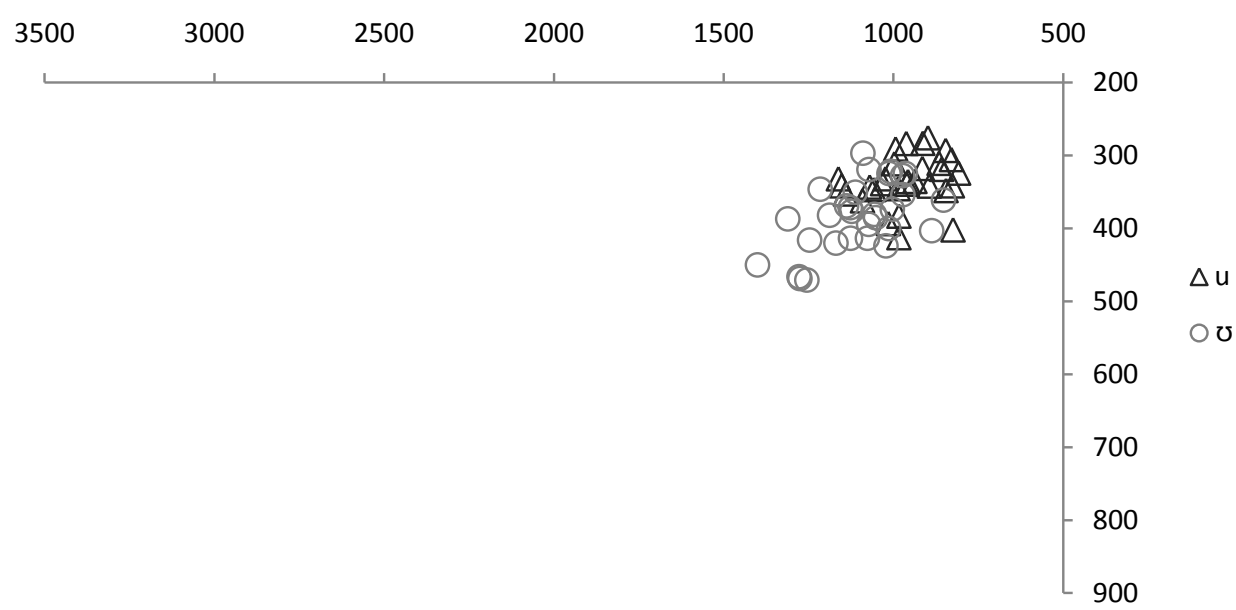

Graph 4: $F_{1}$ and $F_{2}$ of $/ u$ v/ for NNSs 
It is observed that not all NNSs systematically merge their $/ \mathrm{u} /-/ \mathrm{v} /$. Speaker SG invariably relies on the differences in the vowel quality of these two vowels, approximating the pronunciation of NSs of English with a mean value of $469 \mathrm{~Hz}$ for the first formant. However, the native speaker MB has an unusually low values for the first formant with an average measurement of $471 \mathrm{~Hz}$.

\subsubsection{The Vowels $/ \varepsilon \mathfrak{\varepsilon} \Lambda /$}

Vowel data elicited from bet and bat are analyzed next. It has been spotted that there is more variation in the acoustic vowel space even in the case of NSs. There is a tendency, though, for the $/ \varepsilon /$ to be produced with a lower $F_{1}$, which makes it a higher vowel than $/ æ /$ in AE native speech. Three tokens of all three vowels that have consistently lower values of $F_{1}$ are all produced by speaker MB. This may be due to his vocal tract length, which is longer in tall people. This reduction in $F_{1}$ values in one speaker may be seen as his idiosyncratic characteristic.

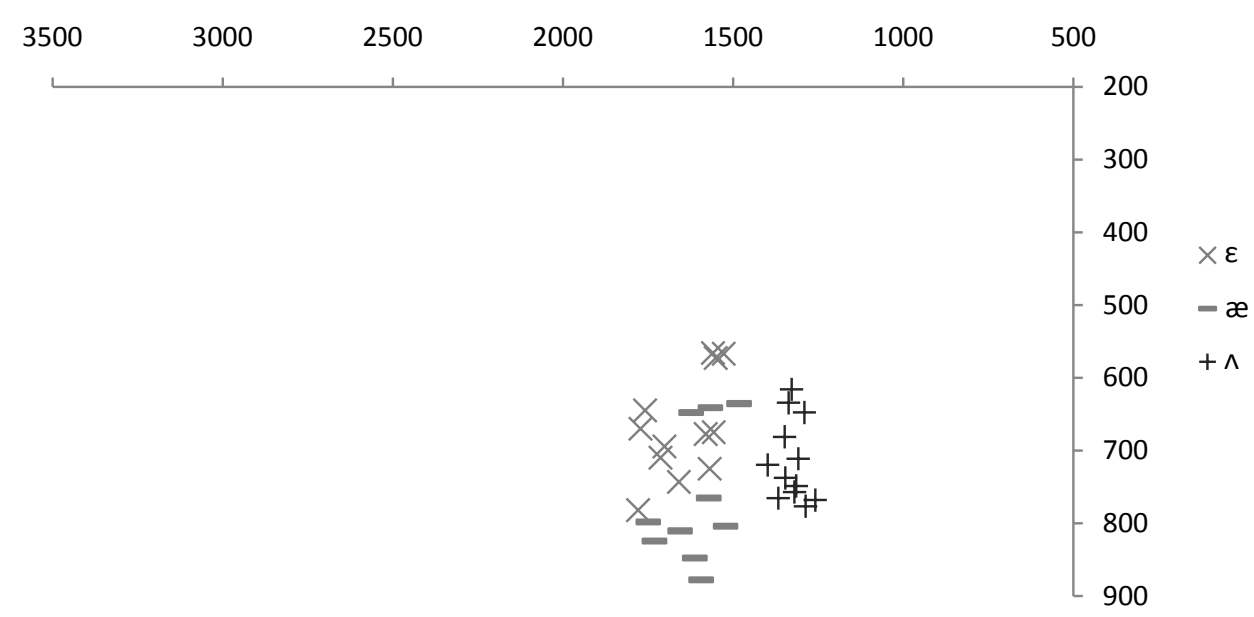

Graph 5: $F_{1}$ and $F_{2}$ of $/ \varepsilon æ \Lambda /$ for NSs

The NNS participants in this study tend to merge $/ \varepsilon /$ and $/ \mathfrak{m} /$ into one vowel, i.e. they do not clearly differentiate between the two. Both vowels are new sounds to Serbian language speakers. However, there are nine tokens of the bat vowel in Graph 6 that have higher $F_{1}$ values and they are repetitions of 3 speakers, SG, NN and UZ. Two of these participants have a relatively long LOR in the States, 23 and 16 years. The speaker NN has lived in the States for 13 years, which is slightly under the mean value for LOR in the study -13.5 years. 


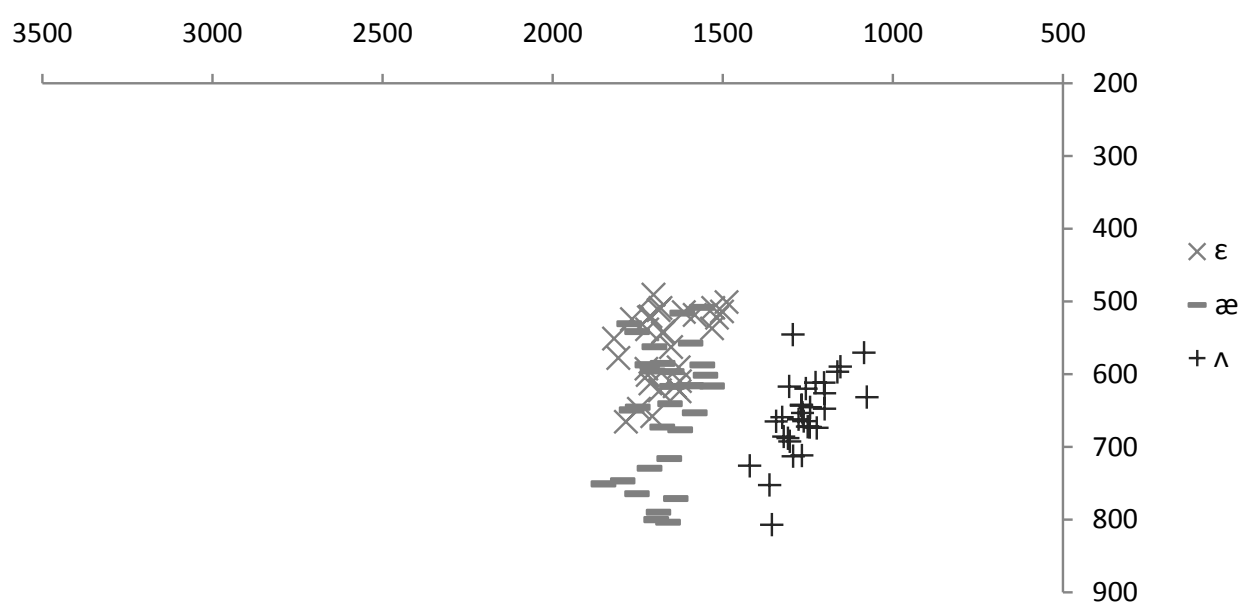

Graph 6: $\mathrm{F}_{1}$ and $\mathrm{F}_{2}$ of $/ \varepsilon æ \Lambda /$ for NNSs

A similar dispersion between the two groups of participants is observed for the $F_{1}$ values of $/ \Lambda /$ - mostly between 600 and $800 \mathrm{~Hz}$. However, one NNS consistently lowers the $F_{1}$ values, keeping them steady at slightly below $600 \mathrm{~Hz}$. This feature is treated as a speech habit of speaker NN. The same speech habit is observed in 2 tokens of speaker IS. On Graph 7, all tokens of $/ \Lambda /$ for both native and non-native speakers are plotted, except for speaker NN who systematically produced this vowel as higher. The two rightmost tokens represent the speech of speaker IS.

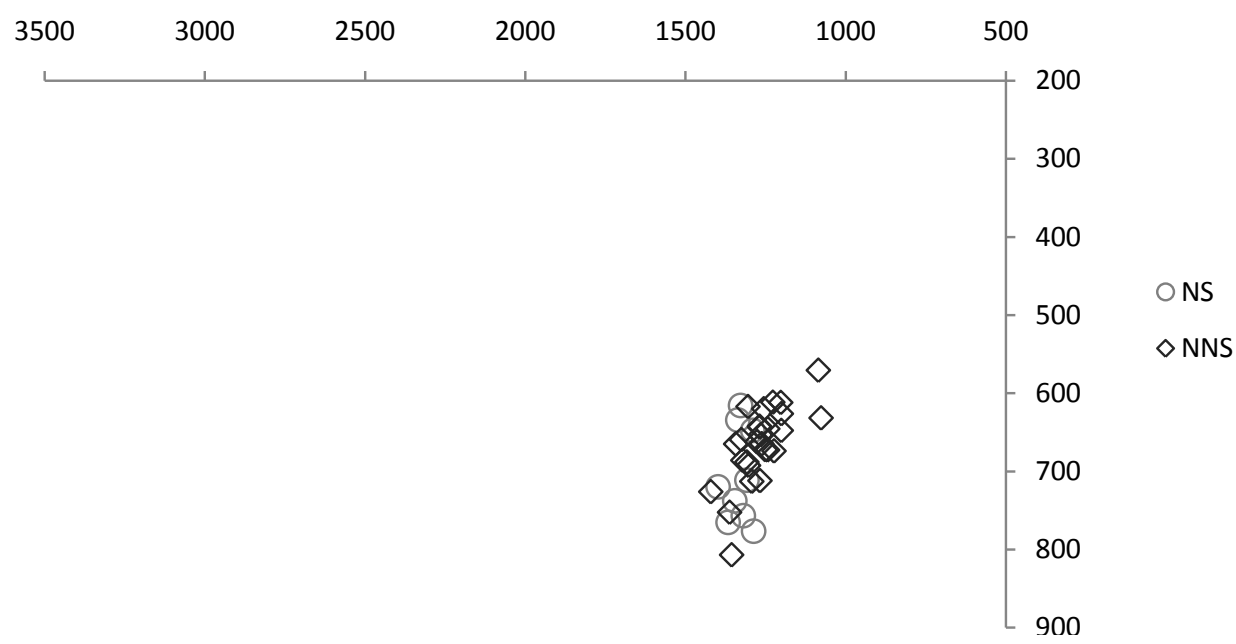

Graph $7: / \Lambda /$ in 4 NSs and 9 NNSs 


\subsubsection{The Vowels /o a/}

Both $/ \mathrm{s} /$ and $/ \mathrm{a} /$ are described as back vowels in AE. However, in AE a cot-caught merger is observed in many regions. As a result of this phonological process, the two vowels become one (homophonous). This speech characteristic is also typical of other varieties of English, Canadian English in particular.

The NS participants of this study mostly differentiate the vowels in the corpus, i.e. in the words bought and pot. The NNSs utilize the same speech habit as NSs. However, the $/ \mathrm{J} /$ vowel is articulated with a lower $\mathrm{F}_{2}$ by most subjects in the NNS cohort. This implies that the NNS $/ 0 /$ is a more back vowel than in native AE speech. The mean values of the second formant for the two groups are $1181 \mathrm{~Hz}$ (NSs) and $885 \mathrm{~Hz}$ (NNSs). In addition, the measurements of $F_{1}$ for the NS group are significantly higher compared to the non-native speaking participants, which implies that $/ \mathrm{J} /$ is a lower vowel in the native AE speech.

The vowel of pot shares the same phonetic characteristics as /a/ in the two groups of participants in this study. The values for both formants are lower in the NNS. This vowel is, therefore, produced as a higher vowel and with a larger degree of backness.

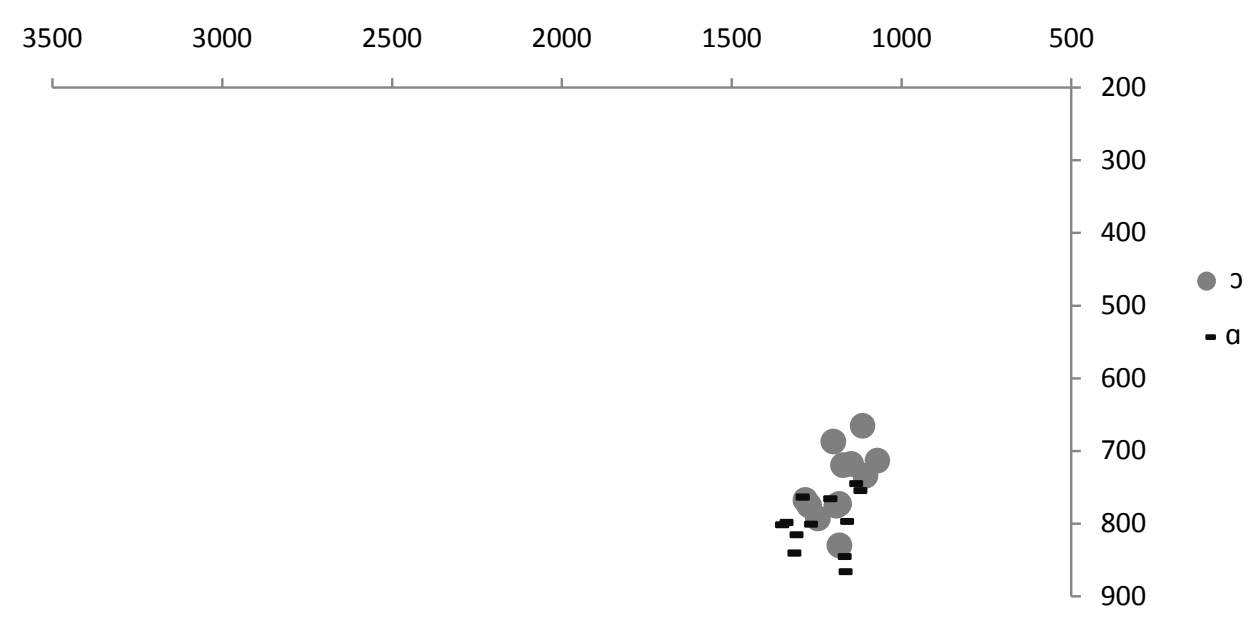

Graph 8: $F_{1}$ and $F_{2}$ of $/ 0 \mathrm{a} /$ for NSs

A glimpse at the individual speakers reveals more interesting acoustic data that needs to be discussed. Namely, three NNS speakers drift towards the higher values of $\mathrm{F}_{1}$ and $\mathrm{F}_{2}$, i.e. they are moving towards a more native-like pronunciation of the vowels $1 \mathrm{o} \mathrm{a} /$. These are speakers SG, MS and NN. The LOR is, indeed, longer for SG and MS, and NN's LOR is 13 years. LOR may be considered an important factor progressively leading to a more native-like pronunciation of $\mathrm{L} 2$. 


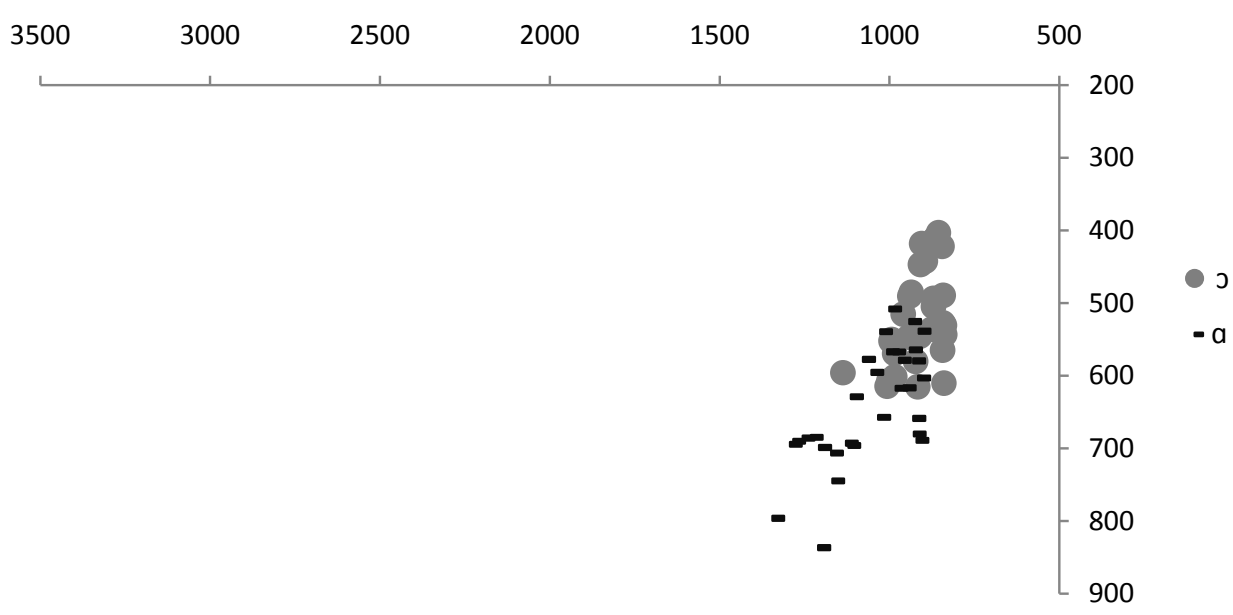

Graph 9: $F_{1}$ and $F_{2}$ of $/ 0 a /$ for NNSs

\section{GENERAL DISCUSSION AND CONCLUSIONS}

The tables that follow summarize the mean values of the first two formants for all nine vowels investigated in this research study. The measurements for native American English speakers are given in Table 3.

Table 3: Mean values of $F_{1}$ and $F_{2}$ of vowels produced by NSs

\begin{tabular}{|l|l|l|l|l|l|l|l|l|l|}
\cline { 2 - 10 } \multicolumn{1}{c|}{} & $/ \mathrm{i} /$ & $/ \mathrm{I} /$ & $/ \varepsilon /$ & $/ \mathfrak{l} /$ & $/ \mathrm{N} /$ & $/ \mathrm{u} /$ & $/ \mathrm{U} /$ & $/ \mathrm{J} /$ & $/ \mathrm{a} /$ \\
\hline $\mathrm{F}_{1}$ & 316 & 500 & 668 & 765 & 713 & 359 & 548 & 745 & 799 \\
\hline $\mathrm{F}_{2}$ & 2857 & 1791 & 1644 & 1610 & 1325 & 1220 & 1306 & 1181 & 1252 \\
\hline
\end{tabular}

The acoustic data from Hillenbrand et al. (1995) differs significantly from the $F_{1}$ and $\mathrm{F}_{2}$ measurements in this study. There is no clear pattern in the differences between the acoustic measurements in their study and the present study. This may be accounted for by the method that was used in obtaining the measurements. This vowel study applies a different methodological approach to acoustic measurements, which extracts dynamic vowel data over three points in time. The average vowel frequencies for the speakers of Serbian language background are provided in Table 4.

Table 4: Mean values of $F_{1}$ and $F_{2}$ of vowels produced by NNSs

\begin{tabular}{|l|l|l|l|l|l|l|l|l|l|}
\cline { 2 - 10 } \multicolumn{1}{c|}{} & $/ \mathrm{i} /$ & $/ \mathrm{I} /$ & $/ \mathrm{\varepsilon} /$ & $/ \mathfrak{a} /$ & $/ \mathrm{N} /$ & $/ \mathrm{u} /$ & $/ \mathrm{U} /$ & $/ \mathrm{J} /$ & $/ \mathrm{a} /$ \\
\hline $\mathrm{F}_{1}$ & 273 & 321 & 561 & 647 & 656 & 334 & 383 & 507 & 640 \\
\hline $\mathrm{F}_{2}$ & 2139 & 2020 & 1666 & 1672 & 1259 & 960 & 1103 & 885 & 1068 \\
\hline
\end{tabular}


The biggest differences in the acoustic measurements of the two groups lie in those vowels where NNSs merge two vowel qualities of American English, abolishing the contrast. This merger is observed in three pairs of vowels: $/ \mathrm{i}_{\mathrm{I}}^{\mathrm{I}} /, / \mathrm{u} \mathrm{U} /$, and $/ \varepsilon æ /$. The neglect of the vowel quality differences between the two vowels in each pair is compensated by non-native speakers' choice to rely on the phonetic duration solely - the phonological property they transferred from their mother tongue. The $/ \Lambda /$ vowel seems to display the least acoustic differences in native and non-native speech. Finally, /o/ and /a/ are consistently produced as more back and lower vowels in NNs than in NS.

As a final note, with the exception of $/ \mathrm{N} /$, which is a good match in the non-native speaker group, it seems that only 4 participants from the NNS cohort approach the acoustic characteristics of native AE speech. This is especially noticeable in their tendency to avoid mergers of vowels, which is the main characteristic of American English speech of non-native speakers of Serbian language background. The LOR of three of these speakers (SG (23y), UZ (16y) and MS (15y) is longer than the average LOR in this study and it may have influenced the resistance to the non-native merger of similar vowel qualities.

\section{References}

BOERSMA, Paul/David WEENINK (2013) "Praat: doing phonetics by computer. Version 5.3.51." http://www.praat.org/

BROWNE, E. Wayles/James D. MCCAWLEY (1965) "Srpskohrvatski akcenat." Zbornik za filologiju i lingvistiku 8, 147-151.

DICANIO, Christian (2013) "Script." http://www.acsu.buffalo.edu/ cdicanio/scripts/ Vowel_Acoustics_for_corpus_data.praat

ESCUDERO, Paola/Paul BOERSMA (2004) "Bridging the gap between L2 speech perception research and phonological theory." Studies in Second Language Acquisition 26, 551-585. http://dx.doi.org/10.1017/S0272263104040021

FLEGE, James Emil/Ocke-Schwen BOHN/Sunyoung JANG (1997) "Effects of experience on non-native speakers' production and perception of English vowels." Journal of Phonetics 25/4, 437-470. http://dx.doi.org/10.1006/jpho.1997.0052

HILLENBRAND, James/Laura A. GETTY/Michael J. CLARK/Kimberly WHEELER (1995) “Acoustic characteristics of American English vowels." JASA 97/5-Vol. 1, 3099-3111

INKELAS, Sharon/Draga ZEC (1988) "Serbo-Croatian Pitch Accent: The Interaction of Tone, Stress, and Intonation." Language 64/2, 227-248. http://dx.doi. org/10.2307/415433

IVERSON, Paul/Bronwen G. EVANS (2007) "Learning English vowels with different first-language vowel systems: Perception of formant targets, formant movement, and duration." JASA 122/5, 2842-2854.

JAKOBSON, Roman ([1937] 1962) "On the identification of phonemic entities." In: Selected Writings I. The Hague: Mouton, 418-425. 
KREBS-LAZENDIC, Lidija/Catherine T. BEST (2013) "First language suprasegmentally-conditioned syllable length distinctions influence perception and production of second language vowel contrasts." Laboratory Phonology 4/2, 435-474. http:// dx.doi.org/10.1515/lp-2013-0014

PETERSON, Gordon E./Harold L. BARNEY (1952) "Control methods used in a study of the vowels." JASA 24, 175-184

SOKOLOVIĆ-PEROVIĆ, Mirjana (2009) "Voicing-Conditioned Vowel Duration in Southern Serbian." Newcastle Working Papers in Linguistics 15, 126-137.

THOMSON, Ron I./Terrance M. NEAREY/Tracey M. DERWING (2009) "A modified statistical pattern recognition approach to measuring the crosslinguistic similarity of Mandarin and English vowels." JASA 126/3, 1447-1460.

YAVAŞ, Mehmet (22011) Applied English Phonology. Malden, MA: Wiley-Blackwell.

\section{Abstract \\ THE ACOUSTIC CHARACTERISTICS OF NON-NATIVE AMERICAN ENGLISH VOWELS}

This study aims at discussing the phonetic property of vowel quality in English, as exercised by both native speakers of General American English (AE) and non-native speakers of General American English of Serbian language background, all residents of the United States. Ten Serbian male speakers and four native male speakers of AE are recorded in separate experiments and their speech is analyzed acoustically for any significant phonetic differences, looking into a set of monosyllabic English words representing nine vowels of $\mathrm{AE}$. The general aim of the experiments is to evaluate the phonetic characteristics of $\mathrm{AE}$ vowels, with particular attention to $\mathrm{F}_{1}$ and $\mathrm{F}_{2}$ values, investigate which vowels differ most in the two groups of participants, and provide some explanations for these variations. A single most important observation that is the result of this vowel study is an evident merger of three pairs of vowels in the non-native speech: /i I/, /u $\mathrm{J} /$, and $/ \varepsilon æ /$.

Keywords: American English, Serbian, monophthong, non-native vowel merger, vowel acoustics

\section{Povzetek \\ AKUSTIČNE ZNAČILNOSTI SAMOGLASNIKOV PRI TUJIH GOVORCIH AMERIŠKE ANGLEŠČINE}

Članek obravnava fonetično lastnost kvalitete samoglasnikov v angleščini pri rojenih govorcih ameriške standardne angleščine in tujih govorcih ameriške angleščine srbskega porekla, ki živijo v Združenih državah Amerike. V ločenih poskusih smo posneli deset moških govorcev srbščine in štiri moške govorce ameriške angleščine. Posnetke 
smo akustično analizirali in ugotavljali signifikantne fonetične razlike v naboru devetih angleških enozložnih besed, ki so vsebovale devet samoglasnikov ameriške angleščine. Glavni cilj poskusa je bil ovrednotiti fonetične značilnosti ameriških samoglasnikov s posebnim poudarkom na vrednostih $F_{1}$ in $F_{2}$. Ugotavljali smo, kateri samoglasniki se najbolj razlikujejo pri govorcih obeh skupin, ter poskušali ugotoviti razloge za te razlike. Posebej pomembna ugotovitev, ki izhaja iz te študije samoglasnikov, je zlitje treh samoglasniških parov v govoru tujih govorcev ameriške angleščine: /i I /, /u $\mathrm{J} /$, in / $\varepsilon$ æ/.

Ključne besede: ameriška angleščina, srbščina, enoglasnik, zlitje samoglasnikov pri tujih govorcih, akustika samoglasnikov 